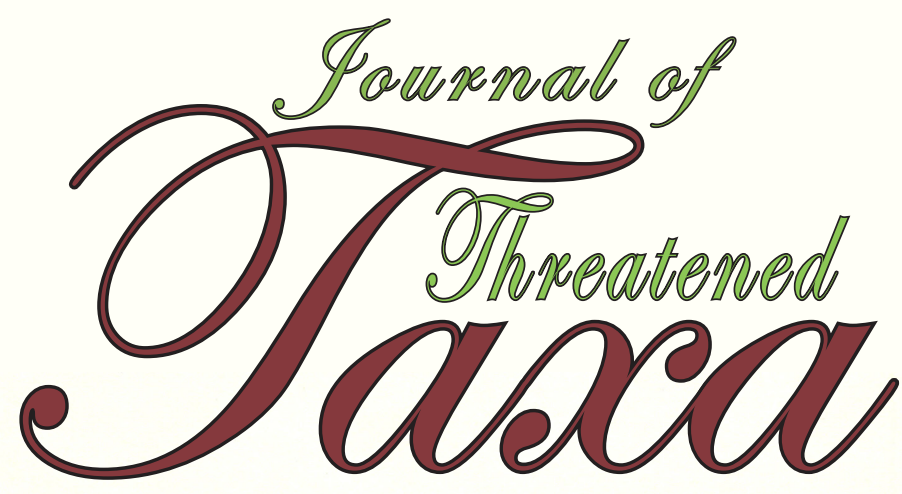

10.11609/jott.2021.13.14.20143-20310 enever.threatenedtaxa.org

26 December 2021 (Online \& Print) Val. 13 | Na. 14 | Pages: 20143-20310 155n 0974-7907 (Online) 155n 0974-7893 (Print)

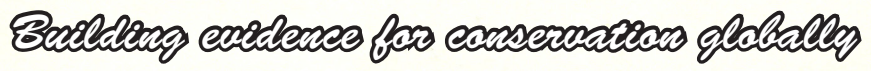

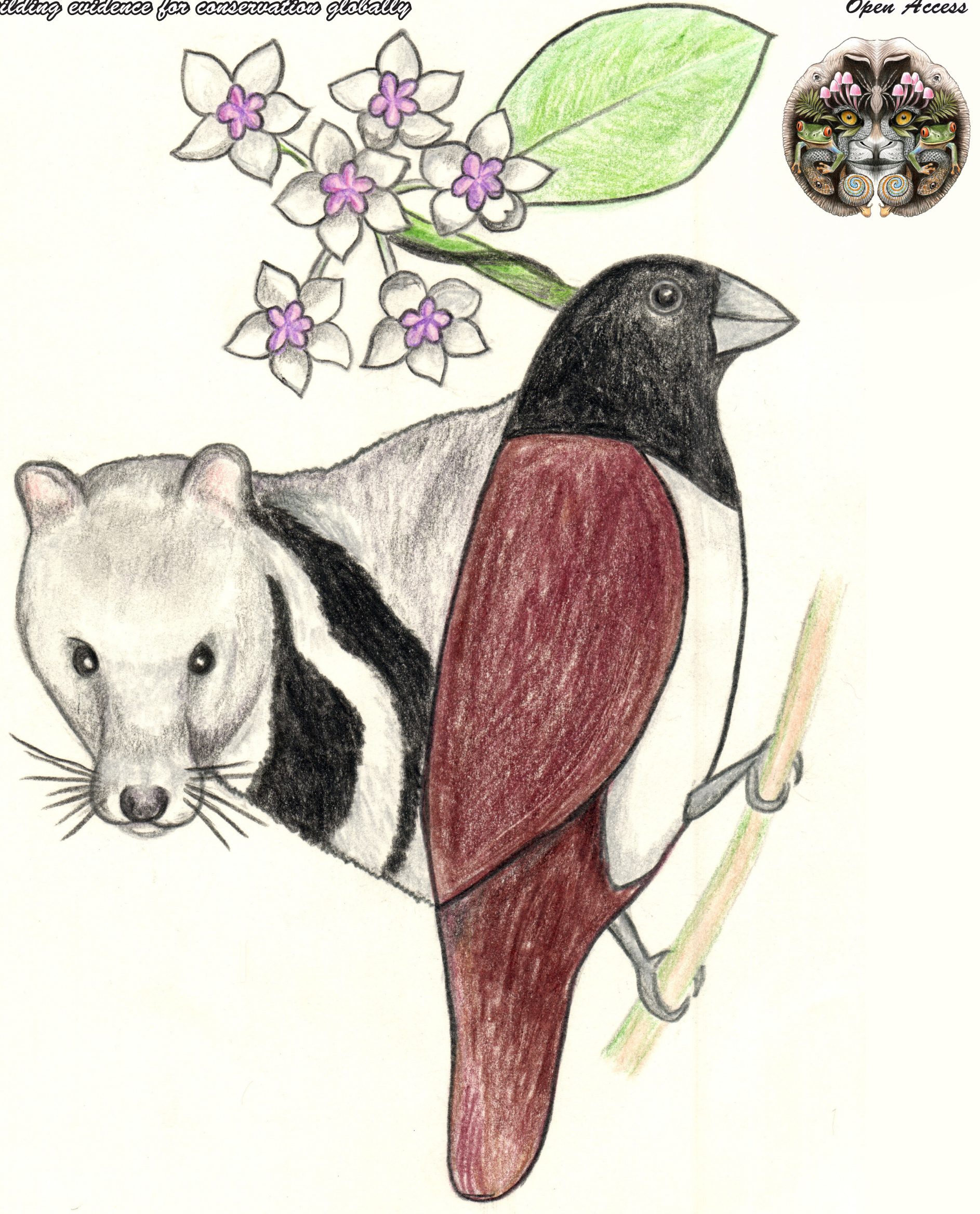

Open Access 


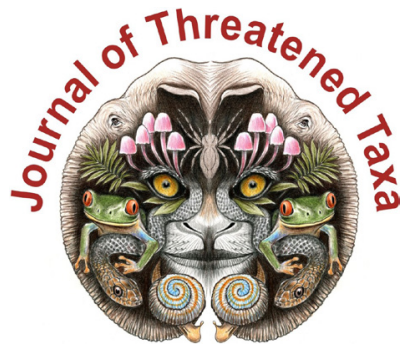

ISSN 0974-7907 (Online); ISSN $0974-7893$ (Print)

Publisher

Host

Wildlife Information Liaison Development Society

www.wild.zooreach.org

Zoo Outreach Organization www.zooreach.org

No. 12, Thiruvannamalai Nagar, Saravanampatti - Kalapatti Road, Saravanampatti, Coimbatore, Tamil Nadu 641035, India

Ph: +91 9385339863 | www.threatenedtaxa.org

Email: sanjay@threatenedtaxa.org

EDITORS

\section{Founder \& Chief Editor}

Dr. Sanjay Molur

Wildlife Information Liaison Development (WILD) Society \& Zoo Outreach Organization (ZOO),

12 Thiruvannamalai Nagar, Saravanampatti, Coimbatore, Tamil Nadu 641035, India

\section{Deputy Chief Editor}

Dr. Neelesh Dahanukar

Noida, Uttar Pradesh, India

\section{Managing Editor}

Mr. B. Ravichandran, WILD/ZOO, Coimbatore, India

\section{Associate Editors}

Dr. Mandar Paingankar, Government Science College Gadchiroli, Maharashtra 442605, India

Dr. Ulrike Streicher, Wildlife Veterinarian, Eugene, Oregon, USA

Ms. Priyanka lyer, ZOO/WILD, Coimbatore, Tamil Nadu 641035, India

Dr. BA. Daniel, $200 / \mathrm{WILD}$, Coimbatore, Tamil Nadu 641035, India

\section{Editorial Board}

Dr. Russel Mittermeie

Executive Vice Chair, Conservation International, Arlington, Virginia 22202, USA

\section{Prof. Mewa Singh Ph.D., FASc, FNA, FNASc, FNAPsy}

Ramanna Fellow and Life-Long Distinguished Professor, Biopsychology Laboratory, and Institute of Excellence, University of Mysore, Mysuru, Karnataka 570006, India; Honorary Professor, Jawaharlal Nehru Centre for Advanced Scientific Research, Bangalore; and Adjunct Professor, National Institute of Advanced Studies, Bangalore

\section{Stephen D. Nash}

Scientific Illustrator, Conservation International, Dept. of Anatomical Sciences, Health Sciences Center, T-8, Room 045, Stony Brook University, Stony Brook, NY 11794-8081, USA

\section{Dr. Fred Pluthero}

Toronto, Canada

\section{Dr. Priya Davidar}

Sigur Nature Trust, Chadapatti, Mavinhalla PO, Nilgiris, Tamil Nadu 643223, India

\section{Dr. Martin Fisher}

Senior Associate Professor, Battcock Centre for Experimental Astrophysics, Cavendish

Laboratory, JJ Thomson Avenue, Cambridge CB3 OHE, UK

\section{Dr. John Fellowes}

Honorary Assistant Professor, The Kadoorie Institute, 8/F, T.T. Tsui Building, The University of Hong Kong, Pokfulam Road, Hong Kong

\section{Prof. Dr. Mirco Solé}

Universidade Estadual de Santa Cruz, Departamento de Ciências Biológicas, Vice-coordenado do Programa de Pós-Graduação em Zoologia, Rodovia Ilhéus/Itabuna, Km 16 (45662-000)

Salobrinho, Ilhéus - Bahia - Brasil

\section{Dr. Rajeev Raghavan}

Professor of Taxonomy, Kerala University of Fisheries \& Ocean Studies, Kochi, Kerala, India

\section{English Editors}

Mrs. Mira Bhojwani, Pune, India

Dr. Fred Pluthero, Toronto, Canad

Mr. P. Ilangovan, Chennai, India

Web Development

Mrs. Latha G. Ravikumar, ZOO/WILD, Coimbatore, India

\section{Typesetting}

Mr. Arul Jagadish, ZOO, Coimbatore, India

Mrs. Radhika, ZOO, Coimbatore, India

Mrs. Geetha, ZOO, Coimbatore India
Fundraising/Communications

Mrs. Payal B. Molur, Coimbatore, India

Subject Editors 2018-2020

Fungi

Dr. B. Shivaraju, Bengaluru, Karnataka, India

Dr. R.K. Verma, Tropical Forest Research Institute, Jabalpur, India

Dr. Vatsavaya S. Raju, Kakatiay University, Warangal, Andhra Pradesh, India

Dr. M. Krishnappa, Jnana Sahyadri, Kuvempu University, Shimoga, Karnataka, India

Dr. K.R. Sridhar, Mangalore University, Mangalagangotri, Mangalore, Karnataka, India

Dr. Gunjan Biswas, Vidyasagar University, Midnapore, West Bengal, India

\section{Plants}

Dr. G.P. Sinha, Botanical Survey of India, Allahabad, India

Dr. N.P. Balakrishnan, Ret. Joint Director, BSI, Coimbatore, India

Dr. Shonil Bhagwat, Open University and University of Oxford, UK

Prof. D.J. Bhat, Retd. Professor, Goa University, Goa, India

Dr. Ferdinando Boero, Università del Salento, Lecce, Italy

Dr. Dale R. Calder, Royal Ontaro Museum, Toronto, Ontario, Canada

Dr. Cleofas Cervancia, Univ. of Philippines Los Baños College Laguna, Philippines

Dr. F.B. Vincent Florens, University of Mauritius, Mauritius

Dr. Merlin Franco, Curtin University, Malaysia

Dr. V. Irudayaraj, St. Xavier's College, Palayamkottai, Tamil Nadu, India

Dr. B.S. Kholia, Botanical Survey of India, Gangtok, Sikkim, India

Dr. Pankaj Kumar, Kadoorie Farm and Botanic Garden Corporation, Hong Kong S.A.R., China

Dr. V. Sampath Kumar, Botanical Survey of India, Howrah, West Bengal, India

Dr. A.J. Solomon Raju, Andhra University, Visakhapatnam, India

Dr. Vijayasankar Raman, University of Mississippi, USA

Dr. B. Ravi Prasad Rao, Sri Krishnadevaraya University, Anantpur, India

Dr. K. Ravikumar, FRLHT, Bengaluru, Karnataka, India

Dr. Aparna Watve, Pune, Maharashtra, India

Dr. Qiang Liu, Xishuangbanna Tropical Botanical Garden, Yunnan, China

Dr. Noor Azhar Mohamed Shazili, Universiti Malaysia Terengganu, Kuala Terengganu, Malaysia

Dr. M.K. Vasudeva Rao, Shiv Ranjani Housing Society, Pune, Maharashtra, India

Prof. A.J. Solomon Raju, Andhra University, Visakhapatnam, India

Dr. Mandar Datar, Agharkar Research Institute, Pune, Maharashtra, India

Dr. M.K. Janarthanam, Goa University, Goa, India

Dr. K. Karthigeyan, Botanical Survey of India, India

Dr. Errol Vela, University of Montpellier, Montpellier, France

Dr. P. Lakshminarasimhan, Botanical Survey of India, Howrah, India

Dr. Larry R. Noblick, Montgomery Botanical Center, Miami, USA

Dr. K. Haridasan, Pallavur, Palakkad District, Kerala, India

Dr. Analinda Manila-Fajard, University of the Philippines Los Banos, Laguna, Philippines

Dr. P.A. Sinu, Central University of Kerala, Kasaragod, Kerala, India

Dr. Afroz Alam, Banasthali Vidyapith (accredited A grade by NAAC), Rajasthan, India

Dr. K.P. Rajesh, Zamorin's Guruvayurappan College, GA College PO, Kozhikode, Kerala, India

Dr. David E. Boufford, Harvard University Herbaria, Cambridge, MA 02138-2020, USA

Dr. Ritesh Kumar Choudhary, Agharkar Research Institute, Pune, Maharashtra, India

Dr. Navendu Page, Wildlife Institute of India, Chandrabani, Dehradun, Uttarakhand, India

\section{Invertebrates}

Dr. R.K. Avasthi, Rohtak University, Haryana, India

Dr. D.B. Bastawade, Maharashtra, India

Dr. Partha Pratim Bhattacharjee, Tripura University, Suryamaninagar, India

Dr. Kailash Chandra, Zoological Survey of India, Jabalpur, Madhya Pradesh, India

Dr. Ansie Dippenaar-Schoeman, University of Pretoria, Queenswood, South Africa

Dr. Rory Dow, National Museum of natural History Naturalis, The Netherlands

Dr. Brian Fisher, California Academy of Sciences, USA

Dr. Richard Gallon, llandudno, North Wales, LL30 1UP

Dr. Hemant V. Ghate, Modern College, Pune, India

Dr. M. Monwar Hossain, Jahangirnagar University, Dhaka, Bangladesh

Mr. Jatishwor Singh Irungbam, Biology Centre CAS, Branišovská, Czech Republic.

Dr. Ian J. Kitching, Natural History Museum, Cromwell Road, UK

Dr. George Mathew, Kerala Forest Research Institute, Peechi, India

For Focus, Scope, Aims, and Policies, visit https://threatenedtaxa.org/index.php/JoTT/aims_scope
For Article Submission Guidelines, visit https://threatenedtaxa.org/index.php/JoTT/about/submissions
For Policies against Scientific Misconduct, visit https://threatenedtaxa.org/index.php/JoTT/policies_various 


\title{
A new species of flat-headed mayfly Afronurus meenmutti (Ephemeroptera: Heptageniidae: Ecdyonurinae) from Kerala, India
}

\author{
Marimuthu Muthukatturaja ${ }^{1}$ (D) \& Chellaiah Balasubramanian ${ }^{2}$ (D) \\ 1,2 Department of Zoology, Thiagarajar College, Madurai, Tamil Nadu 625009, India. \\ ${ }^{1}$ drmkraja83@gmail.com, ${ }^{2}$ ulabc62@gmail.com (corresponding author)
}

\begin{abstract}
A new species of mayfly (Heptageniidae: Ecdyonurinae) Afronurus meenmuttisp. nov. is described based on larvae and imagoes from the state of Kerala, southern India. The main characteristics that distinguish the new species from all other species are in having glossae oblong with two stout spines medially; lingua of hypopharynx deeply cleft; absence of postero-lateral spines on terga and gill I slightly lobate in the nymph. Hind wing with the acute costal process; stout spine dispersed on basal and surface of forceps in the adults.
\end{abstract}

Keywords: Kallar River, mature larva, mayfly, Meenmutti falls, taxonomy, Western Ghats.

The description of the mayfly genus Afronurus was illustrated by Lestage (1924) from Africa. Kimmins (1937) proposed the name Cinygmina for a single species known from India based on adults only with penes differentiation. Wang \& McCafferty (2004) and Kluge (2004) were synonymised the genus Cinygmina with Afronurus (Braasch \& Freitag 2008). Besides, median titillators of penis are reduced: they are either widely separated and diminished (in assamensis (C.), yoshidae (E.), levis (E)), or completely lost. This apomorphy is non-unique, but does not occur in other Heptagenia/ $\mathrm{f} 5=\mathrm{g} 4$. Unique apomorphy of egg equator bears several additional anchors of another structure: the additional anchor is many times larger than a usual anchor, and in coiled condition represents a flat spiral for those reasons they were synonymized with Cinygmina spp. (Koss \& Edmunds 1974; Kopelke 1980; Flowers \& Pescador 1984; Kang \& Yang 1994). Afronurus Lestage is an old world heptageniid genus with 66 species described (Yannai et al. 2017) and includes 48 species from the Oriental region (Kimmins 1937; Braasch \& Soldan 1984, 1987; Flowers \& Pescador 1984; Braasch 1987, 1990, 2005, 2011; Venkataraman \& Sivaramakrishnan 1989; Kang \& Yang 1994; Nguyen \& Bae 2003; Zhou \& Zheng 2003; Braasch \& Boonsoong 2010; Braasch \& Jacobus 2011; Boonsoong \& Braasch 2013). In India, five species of Afronurus have been recorded namely $A$. assamensis Kimmins, 1937, A. curtus Dubey, 1971, A. solangensis Dubey, 1971, A. keralensis Braasch \& Soldan, 1987, and A. kumbakkaraiensis Venkataraman \& Sivaramakrishnan, 1987. For three decades, no species has been described in India. In this study, we describe a new species, Afronurus meenmutti, based on all life stages, from southern India.

\section{MATERIALS AND METHOdS}

The material used in the present investigation was

ZooBank: urn:Isid:zoobank.org:pub:CCF6F48F-2501-4E7D-99A3-070CB676C876

Editor: Anonymity requested.

Date of publication: 26 December 2021 (online \& print)

Citation: Muthukatturaja, M. \& C. Balasubramanian (2021). A new species of flat-headed mayfly Afronurus meenmutti (Ephemeroptera: Heptageniidae: Ecdyonurinae) from Kerala, India. Journal of Threatened Taxa 13(14): 20272-20277. https://doi.org/10.11609/jott.7580.13.14.20272-20277

Copyright: (c) Muthukatturaja \& Balasubramanian 2021. Creative Commons Attribution 4.0 International License. JoTT allows unrestricted use, reproduction, and distribution of this article in any medium by providing adequate credit to the author(s) and the source of publication.

Funding: MoEFCC (AICOPTAX). F.No. 22018/05/2018-RE (TAX).

Competing interests: The authors declare no competing interests.

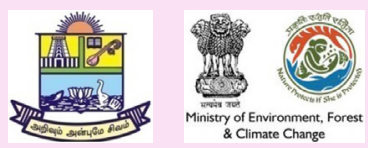

Acknowledgements: Senior author (CB) thanks the Ministry of Environment, Forest and Climate Change - AICOPTAX (F. No: 22018/05/2015) for financial assistance. Authors are grateful to the Management of Thiagarajar College, for their constant support and encouragement. 
preserved in $95 \%$ ethanol. The nymphs were collected by kick-net method in the riffle habitats on moderate to fast-flowing streams. Ample numbers of collected mature nymphs were kept in a plastic tray filled with cobbles and pebbles in the natural habitat covered with a mosquito net $(1 \times 2 \mathrm{~m})$. The modified emergence trap was retained until adult emergence. This emergence trap was monitored each day in the morning and evening until all adults had emerged. Imagoes were carefully removed from the net and preserved in 95\% alcohol. The collected specimens were examined using a NIKON 1270 i stereo zoom binocular microscope. Drawings were prepared using a camera lucida. Holotype and paratypes were deposited in the Zoological Survey of India (in alcohol), Southern Regional Centre, Chennai, Tamil Nadu, India.

\section{RESULTS}

\section{Afronurus meenmutti Balasubramanian \& Muthukatturaja sp. nov.}

(Figure 1-18)

urn:Isid:zoobank.org:act:6F9F7C16-2C22-4B3B-AB0D-9C3DE1232CDA

Type material: Holotype (in ethanol): Reg.No. ZSISRC/ I/E 425, 12.v.2018, one mature nymph, India, Kallar River, Kallar, Trivandrum District, Kerala State, India, $08.711^{\circ} \mathrm{N}, 77.128^{\circ} \mathrm{E}, 839 \mathrm{~m}$, coll. M. Muthukatturaja \& C. Balasubramanian.

Paratypes (same data as holotype): Reg.No. ZSI-SRC/ I/E 426, 5 mature nymphs deposited in Zoological Survey of India (Southern Regional Centre), Chennai, Tamil Nadu.

Mature Nymph: (Figures 1-13) (preserved in 95\% ethanol) Dimensions $(\mathrm{mm})$ : body length (excluding cerci) 6.5; cerci length 1.84 times longer than body length; median caudal filament 12.0; width of head 2.0; antennae length 1.0. General body coloration brownishyellow; legs brown.

Head: Dorsum brownish-yellow; scape and pedicel of antennae dark brown, flagellum pale. Mouthparts: emargination of labrum slightly concave (Figure 1); anterior margin with row of stout spines, size of stout spine increases anterolaterally; dorsum with sparse long setae and a clump of hair-like setae directed anteromedially on either side of dorsomedial margin. Right mandible (Figure 2a): incisors trifurcated with numerous serrations; inner incisor with 6-9 hairs laterally; molar with a thick spine at apex, below the molar 7 thin long setae present, clump of bipectinate setae present between molar and prostheca; $1 / 2$ of lateral margin with thin long hairs apically; prostheca with bipectinate processes. Left mandible (Figure $2 b$ ): incisors trifurcated with serrations; below the molar three long thin setae present. Maxilla (Figure 3): maxillary palp three-segmented; segment III much smaller than segment I \& II; outer margin of segment II with long thin hairs and rows of thin setae apically; $1 / 3$ of inner margin of segment II with short spines; segment I with long hairs at inner and outer margin; galea-lacinia with three acute spines; base of galea with clump of bipectinate setae, ventral base of galea-lacinia with numerous long hairs and 9-15 thin long setae; apex of galea-lacinia with row of comb-like setae. Lingua of hypopharynx (Figure 4) deeply cleft; sublingua slender deeply curved inwardly with long setae at anterior and lateral margin. Labium (Figure 5): two segmented labial palp; basal segment larger than apical segment; outer margin of apical segment with tufts of thin setae, inner margin with clump of short spines; glossae oblong with two stout spines medially (Figure 6); ventral margin with long thin setae; outer margin of glossae with row of long bipectinate setae; posterior and mesal margins of paraglossae with row of thin spines; anterior margin with a row of long setae.

Thorax: Brown, median suture pale, small pale maculae on pro and mesonotum. Legs: femora with scattered prominent brown maculae and median transverse band in fore and hindlegs, midleg macula scattered. Foreleg (Figure 7): length of femora; tibia; tarsi; claw viz., 4.0: 3.7: 1.0: 0.4. femora with row of long monopectinate setae at outer margin, inner margin and dorsal surface with sparse spatulate setae; outer margin of tibia with row of long setae and inner margin with row of few blunt spines, mesal margin with row of few spatulate setae; mesal margin of tarsi with 3 spatulate setae; claw slender, slightly curved with 5 denticles. Midleg (Figure 8): length of femora; tibia; tarsi; claw viz., 4.0: 3.7: 1.0: 0.4. coxae with row of very short spines at dorsomedial margin; posterior margin of trochanter with row of six spatulate setae; femora, tibia, tarsi and claw similar to foreleg. Hindleg (Figure 9): length of femora; tibia; tarsi; claw viz., 4.5: 3.7: 1.2: 0.3. coxa similar to midleg; trochanter similar to midleg except seven spatulate setae at posterior margin; femora similar to midleg except few blunt spines distally; tibia of inner margin with row of spines and with three long blunt spines at apically, distal margin with long blunt spine, mesal margin with row of bipectinate hairs; tarsi with three spatulate setae at apically and with row of very short spines at inner margin; claw hooked with 5 denticles.

Abdomen: Tergum brownish-yellow, sternum yellow; 


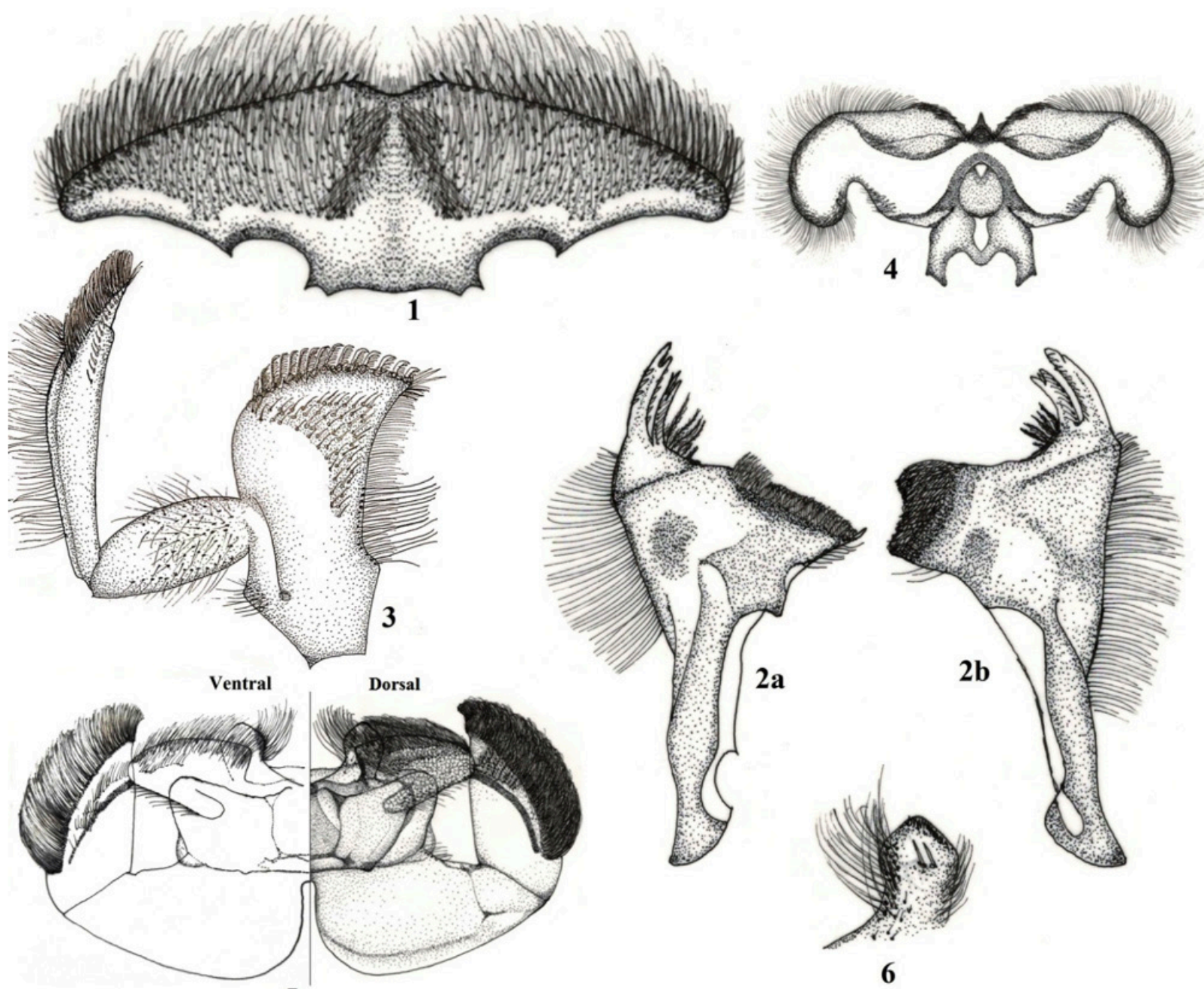

5

Figure 1-6. Mature larva of Afronurus meenmutti sp. nov. (dorsal view): 1-Labrum | 2a-Right mandible | 2b-Left mandible | 3-Maxilla | 4-Hypopharynx | 5-Labium | 6-Glossa enlarged.

posterior margin of terga IV-X with brown band medially; absence of postero-lateral spines in all terga; terga IIIVII dark brown with pale yellow maculae, terga VIII-X washed yellow. Gills on abdominal segments (Figure 10-13) I-VI smoky black to translucent, dorsal lamella tracheated, ventral fimbriate; gill I slightly lobate; gill lamellae on abdominal segment 5 with acutely pointed apical elongation; gill VII single lamellate with well developed tracheation. Cerci brown at posterior region of each segment and reminders translucent.

Male imago: (Figures 14-18) (preserved in 95\% ethanol) Dimensions ( $\mathrm{mm}$ ): Length: body, 7.5; forewings (Figure 14), 6.5; hindwing (Figure 15), 1.8. Width: forewings, 2.3; hindwing, 0.8; cerci, 17.0.

Head: length 0.5 , light yellowish-brown, margin darker. Antennae 0.7, scape and pedicel of antennae yellowish brown, flagellum pale gray. Eyes whitish- black. Basal half of ocelli black, apical half white. Dorsal diameter of eye 0.4 ; distance between compound eyes 0.1 .

Thorax: Yellowish-brown, sutures pale; margins of pronotum brown; venter yellowish-brown. Legs yellowish-brown, all joints of femora, tibiae and tarsi dark brown, ratio of segments in forelegs (Figure 16) femur; tibia; tarsus viz., 2.0/ 2.15/ 3.3, claws pair alike, apically hooked with an opposing hook (Figure 17). Wings longitudinal and cross vein of fore and hind wings pale brown; membranous fore and hind wings hyaline, except cells $\mathrm{C}$ and Sc of fore wing pale gray; stigmatic area of forewing with 12 intercalary veins; MA forked near $1 / 2$ of distance from the base of wing to margin; MP forked at $1 / 4$ of distance from the base of wing to margin; anal veins with two fork; first anal area without pair of long intercalary; hind wing transparent, costal 


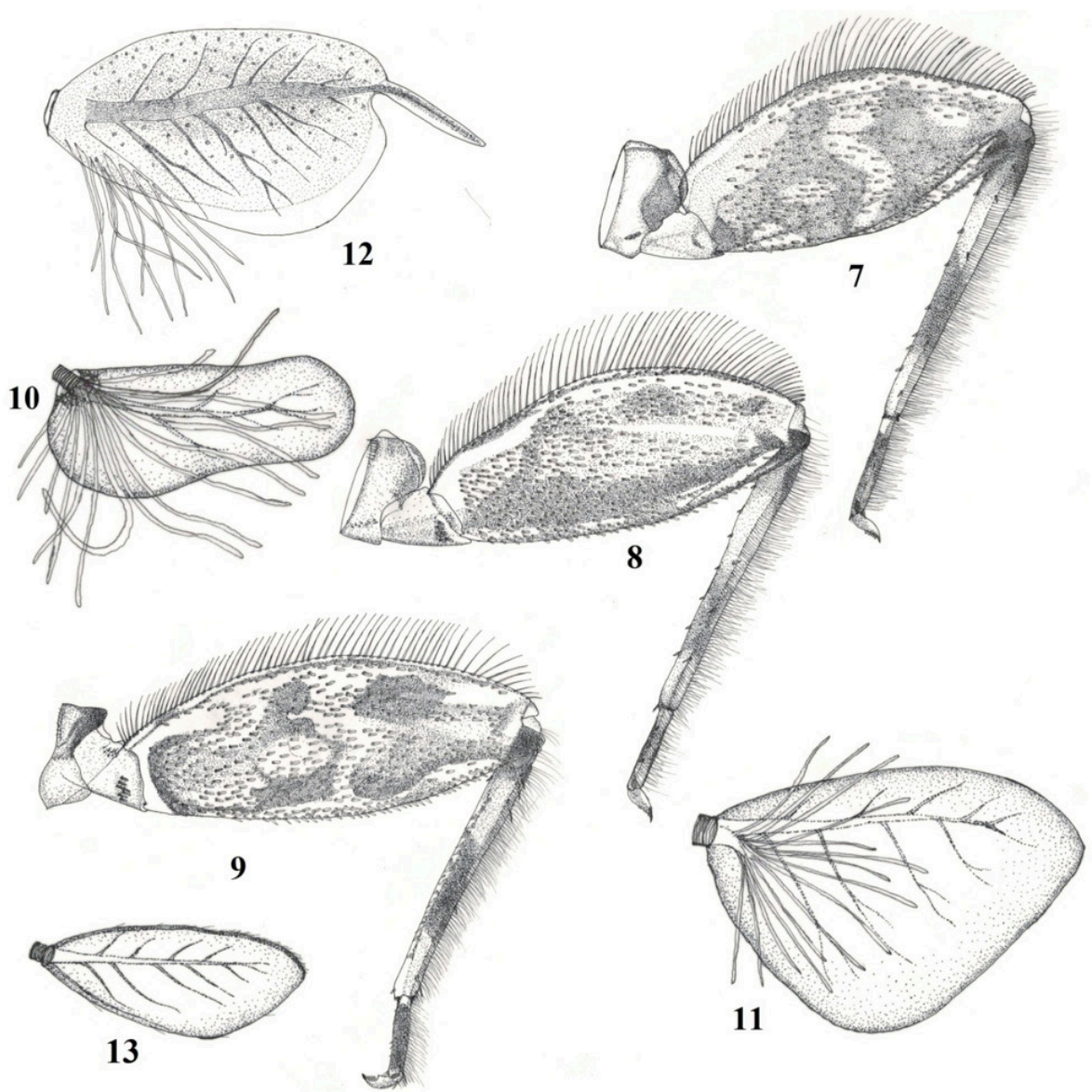

Figure 7-13. Mature larva of Afronurus meenmutti sp. nov.: 7-Foreleg | 8-Midleg | 9-Hindleg | 10-Gill | | 11-Gill V | 12-Gill VI | 13-Gill VII.
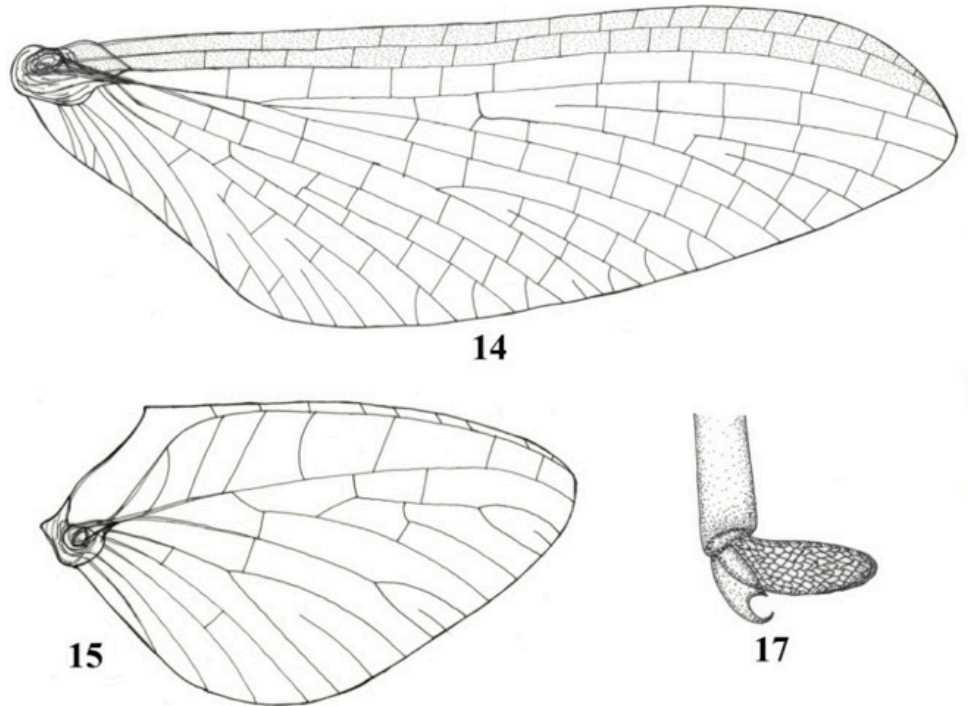

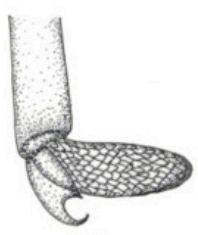

17

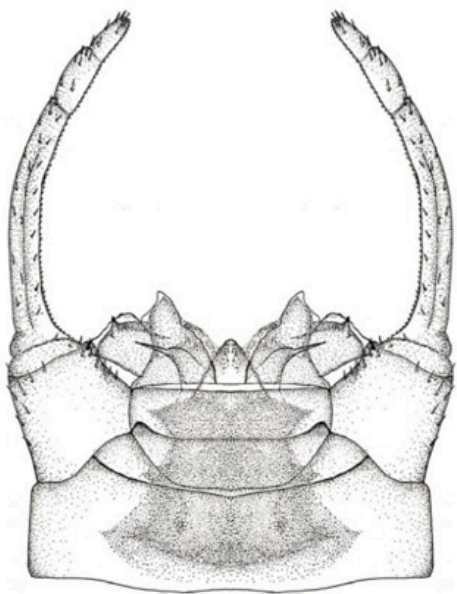

18

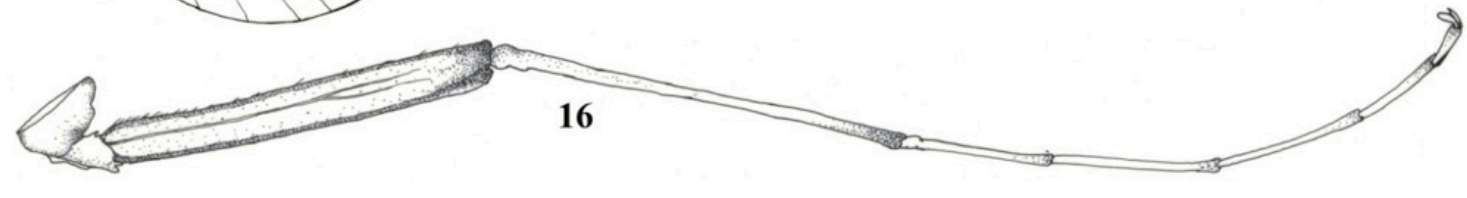

Figure 14-18. Adult of Afronurus meenmutti sp. nov.: 14-Forewing | 15-Hindwing | 16-Foreleg | 17-Foreclaw | 18-Genitalia (ventral view). 
process acute.

Abdomen: Terga I-X washed with dark brown medially; terga washed yellow laterally except terga VII-X washed with yellowish-brown, lack of marking in postero-lateral edges of abdominal terga, terga I-X dark brown band on posterior margin medially; sterna yellowish-brown. Genitalia (Figure 18) forceps 0.7; penes 0.251 ; penes pale yellow; basal half of forceps uniformly washed with yellowish-brown, apical half pale brown; stout spine dispersed on inner and outer margin of forceps; outer lobe of penis much broader and slightly elevated; median titillators of penes well developed and prominent; cerci pale brown, annulations at articulations paler.

Female imago: (preserved in 95\% ethanol) Dimensions (mm): Length: body, 8.5; forewings, 8.1; hindwing, 2.1. Width: forewings, 2.6; hindwing, 0.9; cerci, 19.0.

Head: Length 1.0 , dark brown, margin darker. Antennae 0.8 , scape, pedicel and flagellum of antennae as in male imago. Eyes and ocelli black. Dorsal diameter of eye 0.35 ; distance between compound eyes 0.8 .

Thorax: Brownish-yellow, venter pale yellow; carinae darker; sutures paler. Legs femora of foreleg brownishyellow remainders as in male imago, middles and hindleg yellow. Wings details as in male imago.

Abdomen:terga $\mathrm{I}-\mathrm{X}$ yellowish-brown, posterior edges of all terga with dark brown band. Sterna yellow. Cerci pale yellow, annulations at articulation paler.

\section{Etymology}

The described new species is named after the place of collection, Meenmutti falls of Kallar River, Thiruvanandhapuram district, Kerala.

\section{Diagnosis}

The larvae of Afronurus meenmutti sp. nov. can be separated from all other species by the following combination of characters: (i) lingua of hypopharynx deeply cleft; (ii) glossae oblong with two stout spines medially (iii) gill I slightly lobate (Figure 10); (iv) gill lamellae on abdominal segment $\mathrm{V}$ with acutely pointed apical elongation; (v) absence of postero-lateral spines on terga; (vi) maculae on midleg scattered (Figure 7-9). The imagoes of Afronurus meenmutti sp. nov. can be separated from all other species by the following combination of characters: (i) hind wing with acute costal process; (ii) outer lobe of penis much broader and slightly elevated; (iii) stout spines on forceps.

\section{Discussion}

The flat-headed mayfly genus Afronurus has been recorded in the Palearctic and Oriental regions. In India, six species have been recorded. Of these, $A$. kumbakkaraiensis and $A$. meenmutti sp. nov. have all life stages described, whereas $A$. assamensis, $A$. curtus, and $A$. solangensis are known from adults and only the larvae of $A$. keralensis has been described.

The larvae of $A$. meenmutti sp. nov. differs from $A$. kumbakkaraiensis and $A$. keralensis by the following combination of characters: 1) gill I slightly lobate, 2) gill lamellae on abdominal segment $\mathrm{V}$ with acute apical elongation, 3) lingua of hypopharynx deeply cleft, 4) posterior-lateral spines absent on terga, 5) glossae oblong with 2 spines medially.

Male imagoes of $A$. meenmutti sp. nov. can be distinguised from $A$. kumbakkaraiensis and $A$. assamensis by the following combination of characters: (i) stout spine dispersed on basal and surface of forceps and (ii) outer lobe of penis much broader and slightly elevated. Female imagoes of $A$. meenmutti $\mathrm{sp}$. nov. can be distinguised from $A$. kumbakkaraiensis, $A$. assamensis, $A$. curtus, and $A$. solangensis by the following combination of characters: (i) stigmatic area of forewing with 12 intercalary; (ii) size of fore and hind wings are smaller.

\section{REFERENCES}

Boonsoong, B. \& D. Braasch (2013). Heptageniidae (Insecta Ephemeroptera) of Thailand. ZooKeys 272: 61-93. https://doi. org/10.3897/zookeys.272.3638

Braasch, D. (1987). Neue Heptageniidae von Indien (Ephemeroptera). Reichenbachia 24(18): 131-134.

Braasch, D. (1990). Neue Eintagsfliegenaus Thailand, nebsteinigen Bemerkungenzuderengenerischem Status (Insecta, Ephemeroptera: Heptageniidae). Reichenbachia 28(2): 7-14.

Braasch, D. (2005). Neue Arten der Gattung Atopopus und Afronurus aus Sudostasiensowieeinige Bemerkungenzur Gattung Asionurusvon Malaysia (Insecta: Ephemeroptera: Heptageniidae). Entomologische Abhandlungen 62(2): 165-174.

Braasch, D. (2011). New species of the family Heptageniidae (Ephemeroptera) from Borneo and the Philippines. Deutsche Entomologische Zeitschrift 58(2): 201-219. https://doi.org/10.1002/ mmnd.201100024

Braasch, D. \& B. Boonsoong (2010a). A contribution to the Heptageniidae (Insecta: Ephemeroptera) of Thailand and Malaysia. Zootaxa 2610: 1-26.

Braasch, D. \& B. Boonsoong (2010b). A contribution to the Heptageniidae (Insecta, Ephemeroptera) of Thailand and Malaysia. Zootaxa 2610: 1-26.

Braasch, D. \& H. Freitag (2008). Palawaneuria, a new subgenus of Compsoneuria and new species of Compsoneuria and Afronurus (Ephemeroptera, Heptageniidae) from Palawan, Philippines. Deutsche Entomologische Zeitschrift 55: 117-128.

Braasch, D. \& L. Jacobus (2011) Two new species of Afronurus Lestage, 1924, from Hong Kong, China (Ephemeroptera: Heptageniidae). Zootaxa 062: 64-68.

Braasch, D. \& T. Soldan (1987) Neue Cinygmina-Artenaus Vietnam (Ephemeroptera, Heptageniidae). Reichenbachia 24(16): 123-126. 
Braasch, D. \& T. Soldán (1984). Zweineue Arten der Gattung Cinygmina Kimmins, 1937 aus Vietnam (Ephemeroptera, Heptageniidae). Reichenbachia, Staatliches Museum Tierkunde Dresden 22(26): 195-200.

Braasch, D. \& T. Soldán (1987). Neue Cinygmina-Artenaus Vietnam (Ephemeroptera, Heptageniidae). Reichenbachia, Staatli-ches Museum Tierkunde Dresden 24(16): 123-126.

Dubey, O.P. (1971). Torrenticole insects of the Himalaya. VI. Description of nine new species of Ephemeridae from the northwest Himalaya. Oriental Insects 5: 521-548.

Flowers, R.W. \& M. Pescador (1984). A new Afronurus (Ephemeroptera: Heptageniidae) from the Philippines. International Journal of Entomology 26(4): 362-365.

Kang, S.C. \& C.T. Yang (1994). Heptageniidae of Taiwan (Ephemeroptera). Journal of Taiwan Museum 47(1): 5-36.

Kimmins, D.E. (1937). Some new Ephemeroptera. Annals and Magazine of Natural History, Series 10(19): 430-440.

Kluge, N. (2004). The phylogenetic system of Ephemeroptera. Kluwer Academic Publishers, Dordrecht, 442 pp.

Koss, R.W. \& G.F. Edmunds Jr. (1974). Ephemeroptera eggs and their contribution to phylogenetic studies of the order. Zoological Journa of the Linnean Society 55: 267-349.

Kopelke, J.-P. (1980). Morphologische Studienan den Eiern der Eintagsfliegen (Ephemeroptera) aus der Emergenz des zentralafrikanischen Bergbaches Kalengo. Mitteilungen der Schweizerischen Entomologischen Gesellschaft 53 (2-3): 297-311.
Lestage, J.A. (1924). Les Ephémères de l'Afrique du Sud. Catalogue critique \& systematique des espècesconnueset description de trois genres nouveaux et de septespècesnouvelles. Revue Zoologique Africaine 12: 316-352.

Nguyen, V.V. \& Y.J. Bae (2003). Two new species of Afronurus (Ephemeroptera: Heptageniidae) from Vietnam. Korean Journal of Entomology 33(4): 257-261. https://doi. org/10.1111/j.1748-5967.2003.tb00079

Venkataraman, K. \& K.G. Sivaramakrishnan (1989). A new species of Cinygmina (Ephemeroptera: Heptageniidae) from South India and reevaluation of generic traits of Cinygmina Kimmins, 1937. Hexapoda (Insectalndica) I (1/2): 117-121.

Wang, T.Q. \& W.P. McCaffferty (2004). Heptageniidae (Ephemeroptera) of the world. Part I: Phylogenetic higher classification. Transactions of the American Entomological Society 130: 11-45.

Wu, T., C.F. Chen, N. Cong \& D.S. You (1986). Three species of nymphs of the genus Cinygminafrom Yi Xing. Journal of Nanjing Normal University (Natural Science) 1: 65-70.

Yanai, Z., M. Sartori, R. Dor \& N. Dorchin (2017). Molecular phylogeny and morphological analysis resolve a long-standing controversy over genericconcepts in Ecdyonurinae mayflies (Ephemeroptera: Heptageniidae), Systematic Entomology 42: 182-193.

Zhou, C.F. \& L.Y. Zheng (2003). The genus Cinygmina (Ephemeroptera: Heptageniidae) in China, with description of a new species. Acta Entomologica Sinica 46(6): 755-760. 
Dr. John Noyes, Natural History Museum, London, UK

Dr. Albert G. Orr, Griffith University, Nathan, Australia

Dr. Sameer Padhye, Katholieke Universiteit Leuven, Belgium

Dr. Nancy van der Poorten, Toronto, Canada

Dr. Kareen Schnabel, NIWA, Wellington, New Zealand

Dr. R.M. Sharma, (Retd.) Scientist, Zoological Survey of India, Pune, India

Dr. Manju Siliwal, WILD, Coimbatore, Tamil Nadu, India

Dr. G.P. Sinha, Botanical Survey of India, Allahabad, India

Dr. K.A. Subramanian, Zoological Survey of India, New Alipore, Kolkata, India

Dr. P.M. Sureshan, Zoological Survey of India, Kozhikode, Kerala, India

Dr. R. Varatharajan, Manipur University, Imphal, Manipur, India

Dr. Eduard Vives, Museu de Ciències Naturals de Barcelona, Terrassa, Spain

Dr. James Young, Hong Kong Lepidopterists' Society, Hong Kong

Dr. R. Sundararaj, Institute of Wood Science \& Technology, Bengaluru, India

Dr. M. Nithyanandan, Environmental Department, La Ala Al Kuwait Real Estate. Co. K.S.C.,

Kuwait

Dr. Himender Bharti, Punjabi University, Punjab, India

Mr. Purnendu Roy, London, UK

Dr. Saito Motoki, The Butterfly Society of Japan, Tokyo, Japan

Dr. Sanjay Sondhi, TITLI TRUST, Kalpavriksh, Dehradun, India

Dr. Nguyen Thi Phuong Lien, Vietnam Academy of Science and Technology, Hanoi, Vietnam

Dr. Nitin Kulkarni, Tropical Research Institute, Jabalpur, India

Dr. Robin Wen Jiang Ngiam, National Parks Board, Singapore

Dr. Lional Monod, Natural History Museum of Geneva, Genève, Switzerland.

Dr. Asheesh Shivam, Nehru Gram Bharti University, Allahabad, India

Dr. Rosana Moreira da Rocha, Universidade Federal do Paraná, Curitiba, Brasi

Dr. Kurt R. Arnold, North Dakota State University, Saxony, Germany

Dr. James M. Carpenter, American Museum of Natural History, New York, USA

Dr. David M. Claborn, Missouri State University, Springfield, USA

Dr. Kareen Schnabel, Marine Biologist, Wellington, New Zealand

Dr. Amazonas Chagas Júnior, Universidade Federal de Mato Grosso, Cuiabá, Brasil

Mr. Monsoon Jyoti Gogoi, Assam University, Silchar, Assam, India

Dr. Heo Chong Chin, Universiti Teknologi MARA (UiTM), Selangor, Malaysia

Dr. R.J. Shiel, University of Adelaide, SA 5005, Australia

Dr. Siddharth Kulkarni, The George Washington University, Washington, USA

Dr. Priyadarsanan Dharma Rajan, ATREE, Bengaluru, India

Dr. Phil Alderslade, CSIRO Marine And Atmospheric Research, Hobart, Australia

Dr. John E.N. Veron, Coral Reef Research, Townsville, Australia

Dr. Daniel Whitmore, State Museum of Natural History Stuttgart, Rosenstein, Germany.

Dr. Yu-Feng Hsu, National Taiwan Normal University, Taipei City, Taiwan

Dr. Keith V. Wolfe, Antioch, California, USA

Dr. Siddharth Kulkarni, The Hormiga Lab, The George Washington University, Washington,

D.C., USA

Dr. Tomas Ditrich, Faculty of Education, University of South Bohemia in Ceske

Budejovice, Czech Republic

Dr. Mihaly Foldvari, Natural History Museum, University of Oslo, Norway

Dr. V.P. Uniyal, Wildlife Institute of India, Dehradun, Uttarakhand 248001, India

Dr. John T.D. Caleb, Zoological Survey of India, Kolkata, West Bengal, India

Dr. Priyadarsanan Dharma Rajan, Ashoka Trust for Research in Ecology and the Environment

(ATREE), Royal Enclave, Bangalore, Karnataka, India

\section{Fishes}

Dr. Neelesh Dahanukar, IISER, Pune, Maharashtra, India

Dr. Topiltzin Contreras MacBeath, Universidad Autónoma del estado de Morelos, México

Dr. Heok Hee Ng, National University of Singapore, Science Drive, Singapore

Dr. Rajeev Raghavan, St. Albert's College, Kochi, Kerala, India

Dr. Robert D. Sluka, Chiltern Gateway Project, A Rocha UK, Southall, Middlesex, UK

Dr. E. Vivekanandan, Central Marine Fisheries Research Institute, Chennai, India

Dr. Davor Zanella, University of Zagreb, Zagreb, Croatia

Dr. A. Biju Kumar, University of Kerala, Thiruvananthapuram, Kerala, India

Dr. Akhilesh K.V., ICAR-Central Marine Fisheries Research Institute, Mumbai Research

Centre, Mumbai, Maharashtra, India

Dr. J.A. Johnson, Wildlife Institute of India, Dehradun, Uttarakhand, India

Amphibians

Dr. Sushil K. Dutta, Indian Institute of Science, Bengaluru, Karnataka, India

Dr. Annemarie Ohler, Muséum national d'Histoire naturelle, Paris, France

\section{Reptiles}

Dr. Gernot Vogel, Heidelberg, Germany

Dr. Raju Vyas, Vadodara, Gujarat, India

Dr. Pritpal S. Soorae, Environment Agency, Abu Dubai, UAE.

Prof. Dr. Wayne J. Fuller, Near East University, Mersin, Turkey

Prof. Chandrashekher U. Rivonker, Goa University, Taleigao Plateau, Goa. India

Dr. S.R. Ganesh, Chennai Snake Park, Chennai, Tamil Nadu, India

Dr. Himansu Sekhar Das, Terrestrial \& Marine Biodiversity, Abu Dhabi, UAE
Birds

Dr. Hem Sagar Baral, Charles Sturt University, NSW Australia

Dr. Chris Bowden, Royal Society for the Protection of Birds, Sandy, UK

Dr. Priya Davidar, Pondicherry University, Kalapet, Puducherry, India

Dr. J.W. Duckworth, IUCN SSC, Bath, UK

Dr. Rajah Jayapal, SACON, Coimbatore, Tamil Nadu, India

Dr. Rajiv S. Kalsi, M.L.N. College, Yamuna Nagar, Haryana, India

Dr. V. Santharam, Rishi Valley Education Centre, Chittoor Dt., Andhra Pradesh, India

Dr. S. Balachandran, Bombay Natural History Society, Mumbai, India

Mr. J. Praveen, Bengaluru, India

Dr. C. Srinivasulu, Osmania University, Hyderabad, India

Dr. K.S. Gopi Sundar, International Crane Foundation, Baraboo, USA

Dr. Gombobaatar Sundev, Professor of Ornithology, Ulaanbaatar, Mongolia

Prof. Reuven Yosef, International Birding \& Research Centre, Eilat, Israel

Dr. Taej Mundkur, Wetlands International, Wageningen, The Netherlands

Dr. Carol Inskipp, Bishop Auckland Co., Durham, UK

Dr. Tim Inskipp, Bishop Auckland Co, Durham, UK

Dr. V. Gokula, National College, Tiruchirappalli, Tamil Nadu, India

Dr. Arkady Lelej, Russian Academy of Sciences, Vladivostok, Russia

Dr. Simon Dowell, Science Director, Chester Zoo, UK

Dr. Mário Gabriel Santiago dos Santos, Universidade de Trás-os-Montes e Alto Douro,

Quinta de Prados, Vila Real, Portugal

Dr. Grant Connette, Smithsonian Institution, Royal, VA, USA

Dr. M. Zafar-ul Islam, Prince Saud Al Faisal Wildlife Research Center, Taif, Saudi Arabia

Mammals

Dr. Giovanni Amori, CNR - Institute of Ecosystem Studies, Rome, Italy

Dr. Anwaruddin Chowdhury, Guwahati, India

Dr. David Mallon, Zoological Society of London, UK

Dr. Shomita Mukherjee, SACON, Coimbatore, Tamil Nadu, India

Dr. Angie Appel, Wild Cat Network, Germany

Dr. P.O. Nameer, Kerala Agricultural University, Thrissur, Kerala, India

Dr. Ian Redmond, UNEP Convention on Migratory Species, Lansdown, UK

Dr. Heidi S. Riddle, Riddle's Elephant and Wildlife Sanctuary, Arkansas, USA

Dr. Karin Schwartz, George Mason University, Fairfax, Virginia.

Dr. Lala A.K. Singh, Bhubaneswar, Orissa, India

Dr. Mewa Singh, Mysore University, Mysore, India

Dr. Paul Racey, University of Exeter, Devon, UK

Dr. Honnavalli N. Kumara, SACON, Anaikatty P.O., Coimbatore, Tamil Nadu, India

Dr. Nishith Dharaiya, HNG University, Patan, Gujarat, India

Dr. Spartaco Gippoliti, Socio Onorario Società Italiana per la Storia della Fauna "Giuseppe

Altobello", Rome, Italy

Dr. Justus Joshua, Green Future Foundation, Tiruchirapalli, Tamil Nadu, India

Dr. H. Raghuram, The American College, Madurai, Tamil Nadu, India

Dr. Paul Bates, Harison Institute, Kent, UK

Dr. Jim Sanderson, Small Wild Cat Conservation Foundation, Hartford, USA

Dr. Dan Challender, University of Kent, Canterbury, UK

Dr. David Mallon, Manchester Metropolitan University, Derbyshire, UK

Dr. Brian L. Cypher, California State University-Stanislaus, Bakersfield, CA

Dr. S.S. Talmale, Zoological Survey of India, Pune, Maharashtra, India

Prof. Karan Bahadur Shah, Budhanilakantha Municipality, Kathmandu, Nepal

Dr. Susan Cheyne, Borneo Nature Foundation International, Palangkaraja, Indonesia

Dr. Hemanta Kafley, Wildlife Sciences, Tarleton State University, Texas, USA

\section{Other Disciplines}

Dr. Aniruddha Belsare, Columbia MO 65203, USA (Veterinary)

Dr. Mandar S. Paingankar, University of Pune, Pune, Maharashtra, India (Molecular)

Dr. Jack Tordoff, Critical Ecosystem Partnership Fund, Arlington, USA (Communities)

Dr. Ulrike Streicher, University of Oregon, Eugene, USA (Veterinary)

Dr. Hari Balasubramanian, EcoAdvisors, Nova Scotia, Canada (Communities)

Dr. Rayanna Hellem Santos Bezerra, Universidade Federal de Sergipe, São Cristóvão, Brazil

Dr. Jamie R. Wood, Landcare Research, Canterbury, New Zealand

Dr. Wendy Collinson-Jonker, Endangered Wildlife Trust, Gauteng, South Africa

Dr. Rajeshkumar G. Jani, Anand Agricultural University, Anand, Gujarat, India

Dr. O.N. Tiwari, Senior Scientist, ICAR-Indian Agricultural Research Institute (IARI), New

Delhi, India

Dr. L.D. Singla, Guru Angad Dev Veterinary and Animal Sciences University, Ludhiana, India

Dr. Rupika S. Rajakaruna, University of Peradeniya, Peradeniya, Sri Lanka

Dr. Bahar Baviskar, Wild-CER, Nagpur, Maharashtra 440013, India

Reviewers 2018-2020

Due to pausity of space, the list of reviewers for $2018-2020$ is available online.

The opinions expressed by the authors do not reflect the views of the Journal of Threatened Taxa, Wildlife Information Liaison Development Society, Zoo Outreach Organization, or any of the partners. The journal, the publisher, the host, and the partners are not responsible for the accuracy of the political boundaries shown in the maps by the authors.

Journal of Threatened Taxa is indexed/abstracted in Bibliography of Systematic Mycology, Biological Abstracts, BIOSIS Previews, CAB Abstracts, EBSCO, Google Scholar, Index Copernicus, Index Fungorum, JournalSeek, National Academy of Agricultural Sciences, NewJour, OCLC WorldCat, SCOPUS, Stanford University Libraries, Virtual Library of Biology, Zoological Records.

NAAS rating (India) 5.64
Print copies of the Journal are available at cost. Write to:

The Managing Editor, JoTT,

c/o Wildlife Information Liaison Development Society,

No. 12, Thiruvannamalai Nagar, Saravanampatti - Kalapatti Road,

Saravanampatti, Coimbatore, Tamil Nadu 641035, India

ravi@threatenedtaxa.org 


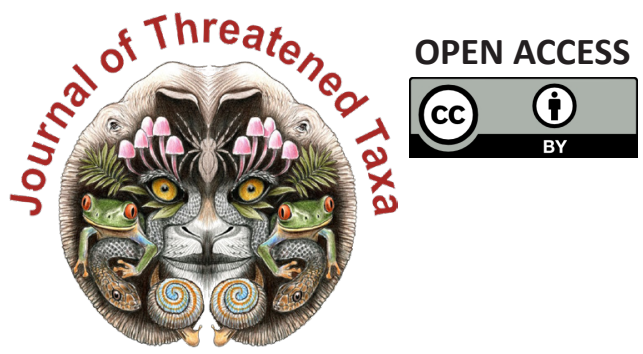

www.threatenedtaxa.org

The Journal of Threatened Taxa (JoTT) is dedicated to building evidence for conservation globally by publishing peer-reviewed articles online every month at a reasonably rapid rate at www.threatenedtaxa.org. All articles published in JoTT are registered under Creative Commons Attribution 4.0 International License unless otherwise mentioned. JoTT allows allows unrestricted use, reproduction, and distribution of articles in any medium by providing adequate credit to the author(s) and the source of publication.

\section{ISSN $0974-7907$ (Online) | ISSN $0974-7893$ (Print)}

\section{December 2021 | Vol. 13 | No. 14 | Pages: 20143-20310 \\ Date of Publication: 26 December 2021 (Online \& Print) DOI: 10.11609/jott.2021.13.14.20143-20310}

\section{Communications}

Updated distribution of seven Trichosanthes L. (Cucurbitales: Cucurbitaceae) taxa in India, along with taxonomic notes

Kanakasabapathi Pradheep, Soyimchiten, Ganjalagatta Dasaiah Harish, Muhammed Abdul Nizar, Kailash Chandra Bhatt, Anjula Pandey \& Sudhir Pal Ahlawat, Pp. 20143-20152

Dragonflies and Damselflies (Insecta: Odonata) of Aryanad Grama Panchayat, Kerala, India

- Reji Chandran \& A. Vivek Chandran, Pp. 20153-20166

Checklist of Odonata (Insecta) of Doon Valley, Uttarakhand, India

- Kritish De, Sarika Bhatt, Amar Paul Singh, Manisha Uniyal \& Virendra Prasad Uniyal, Pp. 20167-20173

Diversity of moths from the urban set-up of Valmiki Nagar, Chennai, India - Vikas Madhav Nagarajan, Rohith Srinivasan \& Mahathi Narayanaswamy, Pp. 20174-20189

Ichthyofaunal diversity with relation to environmental variables in the snowfed Tamor River of eastern Nepal

- Jawan Tumbahangfe, Jash Hang Limbu, Archana Prasad, Bhrarat Raj Subba \& Dil Kumar Limbu, Pp. 20190-20200

Observations on the foraging behavior of Tricoloured Munia Lonchura malacca (Linnaeus, 1766) and its interaction with pearl millet fields in Villupuram District, Tamil Nadu, India

- M. Pandian, Pp. 20201-20208

Roosting patterns of House Sparrow Passer domesticus Linn., 1758 (Aves: Passeridae) in Bhavnagar, Gujarat, India

- Foram P. Patel \& Pravinsang P. Dodia, Pp. 20209-20217

Review

Comprehensive checklist of algal class Chlorophyceae (sensu Fritsch, 1935) for Uttar Pradesh, India, with updated taxonomic status

- Sushma Verma, Kiran Toppo \& Sanjeeva Nayaka, Pp. 20218-20248

\section{View Point}

Wildlife managers ignore previous knowledge at great risk: the case of Rivaldo, the iconic wild Asian Elephant Elephas maximus L. of the Sigur Region, Nilgiri Biosphere Reserve, India

- Jean-Philippe Puyravaud \& Priya Davidar, Pp. 20249-20252

\section{Short Communications}

Diversity and distribution of macro lichens from Kalpetta Municipality of Wayanad District, Kerala, India

- Greeshma Balu, A.R. Rasmi, Stephen Sequeira \& Biju Haridas, Pp. 20253-20257

Extended distribution of two endemic epiphytes from the Western Ghats to the Deccan Plateau

- Sonali Vishnu Deore, Mangala Dala Sonawane \& Sharad Suresh Kambale, Pp. 20258-20260

Nomenclatural notes and report of Boehmeria penduliflora Wedd. ex D.G. Long from the Terai region of Uttar Pradesh, India

- Amit Gupta, Imtiyaz Ahmad Hurrah, Aparna Shukla \& Vijay V. Wagh, Pp. 2026120265
New distribution record of a true coral species, Psammocora contigua (Esper, 1794) from Gulf of Kachchh Marine National Park \& Sanctuary, India - R. Chandran, R. Senthil Kumaran, D.T. Vasavada, N.N. Joshi \& Osman G. Husen, Pp. 20266-20271

A new species of flat-headed mayfly Afronurus meenmutti (Ephemeroptera: Heptageniidae: Ecdyonurinae) from Kerala, India

- Marimuthu Muthukatturaja \& Chellaiah Balasubramanian, Pp. 20272-20277

Photographic record of Dholes predating on a young Banteng in southwestern Java, Indonesia

- Dede Aulia Rahman, Mochamad Syamsudin, Asep Yayus Firdaus, Herry Trisna Afriandi \& Anggodo, Pp. 20278-20283

Latrine site and its use pattern by Large Indian Civet Viverra zibetha Linnaeus, 1758: record from camera trap

- Bhuwan Singh Bist, Prashant Ghimire, Basant Sharma, Chiranjeevi Khanal \& Anoj Subedi, Pp. 20284-20287

Notes

Two additions to the flora of Kerala, India

- P. Murugan, Basil Paul \& M. Sulaiman, Pp. 20288-20291

Pentatropis R.Br. ex Wight \& Arn. (Apocynaceae), a new generic record for Kerala, India

- V. Ambika, Jose Sojan \& V. Suresh, Pp. 20292-20294

New record of Kashmir Birch Mouse Sicista concolor leathemi (Thomas, 1893) (Rodentia: Sminthidae) in the Indian Himalaya

- S.S. Talmale, Avtar Kaur Sidhu \& Uttam Saikia, Pp. 20295-20298

Breeding record of Black-headed Ibis Threskiornis melanocephalus (Aves: Threskiornithidae) at Mavoor wetland, Kozhikode District, Kerala, India - C.T. Shifa, Pp. 20299-20301

\section{Response}

Crop and property damage caused by Purple-faced Langurs Trachypithecus vetulus (Mammalia: Primates: Cercopithecidae) - Vincent Nijman, Pp. 20302-20306

Reply

If habitat heterogeneity is effective for conservation of butterflies in urban landscapes of Delhi, India? Unethical publication based on data manipulation: Response of original authors

- Monalisa Paul \& Aisha Sultana, Pp. 20307-20308

\section{Book Review}

Freshwater fishes of the Arabian Peninsula - Rajeev Raghavan, Pp. 20309-20310

Publisher \& Host

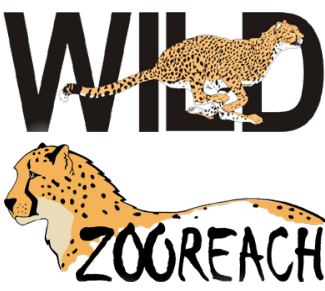

Threatened Taxa 